\title{
A Czech Dictionary of Structuralist Literary Theory and Criticism
}

\author{
Pavel Drábek
}

\begin{abstract}
Ondřej Sládek et al. Slovnik literárněvědného strukturalismu [A Dictionary of Structuralist Literary Theory and Criticism]. Prague/Brno: Institute of Czech Literature of the Czech Academy of Sciences and Host, 2018. 837 pp. ISBN: 978-80-7577-479-8.
\end{abstract}

In its formal structure our idea of a thematic dictionary is closest to Sémiotique: Dictionnaire raisonné de la théorie du langage (A. J. Greimas and Joseph Courtés, 1979) or The Routledge Encyclopaedia of Narrative Theory (David Herman et al., 2005). Their common feature is that the interpretations in individual entries have both historical-comparativist and analytical dimensions. (12; translation PD)

This is the opening statement of aspiration and intent of the present volume, formulated by its indefatigable editor and author of numerous entries Ondřej Sládek. A Dictionary of Structuralist Literary Theory and Criticism, an extensive volume comprising over 320 entries, is an important contribution to Czech literary theory and the related disciplines, synthesising Structuralist scholarship of the past century, and incorporating it carefully into the web of traditions, disciplines and discourses with which the many variants of Structuralism have come into a critical dialogue. While the primary focus is literary theory and criticism - with a soft spot for narratology - the entries also make forays far beyond: 'The dictionary also contains entries from related disciplines: linguistics, aesthetics, semiotics and theatre studies' (12). Many of the listings embrace phi- losophy as well as humanities and social sciences, such as the entries dedicated to 'Story' (Př́běh), 'Myth' (Mýtus), 'Sense and meaning' (Smysl a význam), 'Power' (Moc), and 'Event' (Událost).

The dictionary operates with eight broadly interconnected entry types: Structuralist poetics; aesthetics; linguistics; semiotics; general terms (e.g. function, structure, symbol); theoretical and methodological principles (e.g. interpretation, the Structuralist method); the leading schools and movements; and, sphere of applied Structuralism. The interconnections and relations between individual entries are systematically spelled out. One category that is missing from the book are entries dedicated to individual theorists: the methods and critical theories cannot be separated from the humans who created or refined them. The personal legacies of several illustrious intellectuals such as Roland Barthes, Peter Bogatyrev, Lubomír Doležel, Umberto Eco, Roman Jakobson, Yuri Lotman, Jan Mukařovský, Thomas Sebeok, Tzvetan Todorov, or Jiř́ Veltruský - are perhaps as important as the theories they shaped. Being able to see, synoptically, how much at least some of these individuals contributed to critical theory and practice would certainly be worthwhile. Unfortunately, the dictionary 
does not have an index, which would have gone some way towards mitigating that lack. (Dictionaries generally don't have an index, but a Functional-Structuralist would perhaps feel an urge to pose Ingardenian essential questions of pragmatics, such as what function the dictionary will play and how it will serve its recipients.)

Each of the entries contains meticulous cross-references to other items in the volume as well as a detailed bibliography; with this aspect the dictionary itself is a major accomplishment that does its readers a great service in its rigorous mapping of interdisciplinary sources. Some of the entries are very specific, even to the point of idiosyncratic jargon, such as ' $\mathrm{Hi}$ erarchy of theatrical means' (Hierarchie divadelnich prostředkü), 'Token: token models' (Token: token modely). These articles are less analytical and even less historicalcomparative; they elucidate their genesis and contextualise them within the field. Other entries are mini-studies in their own right, for instance such key concepts as Vít Gvoždiak's entry 'Sign' (Znak), Aleš Merenus' 'Signs in the theatre' (Znaky divadelni), and Zdeněk Hrbata's 'Myth' (Mýtus). Some of these short (or even not so short) essays evidence a great amount of hermeneutic activity, such as Richard Müller's 'Structuralism and Marxism'. Of particular interest are entries negotiating relationships between Structuralism(s) and another discipline, such as David Drozd's 'Structuralism and theatre' (Strukturalismus a divadlo) and Radomír D. Kokeš's 'Structuralism and Film'; such mini-essays document the extent to which the histories of the respective disciplines are inseparable from a history of Structuralist thought.

The range of entries is exhaustive, and yet there are surprising omissions, which is not to say that certain entries had to be included, but a clearer rationale behind the selection criteria could have been provided in the introduction. While there are such edifying entries as 'Secondary modelling systems' (Sekundárni modelujici systémy) on Lotman's theory, and 'Token: token models', focusing on Ivo Osolsobě's idiosyncratic theory, there is no item dedicated to the models as such. Similarly, there are entries on the Peircean triadic terms 'Symbol', 'Index', and 'Icon', but none on metaphor. With a view to the centrality of verbal art in Formalist and FunctionalStructuralist theories, I am missing entries on word and slovesnost (verbal art), inclusions which would have well complemented the entries on 'Language' (Jazyk), 'Literariness' (Literárnost) and others. Conversely, the entry on the journal ' $\mathrm{Tel}$ Quel' seems to be unsystemic, given that much of the material is already covered in 'French Structuralism' (Francouzský strukturalismus) and no other entries in the volume are dedicated to publication platforms, even those that also fulfilled the function of an intellectual community.

These critical objections notwithstanding, this dictionary is a wonderful and important piece of scholarship that will be an essential companion to any student of literary theory and criticism, irrespective of the discipline from which they access it. Thanks to its organisation, the overall concept of the dictionary and the editorial care, the book can be used not only as an encyclopaedia, but also as a handy introduction to the Structuralisms (sic) as they permeate pretty much any humanities discipline of today.

A Dictionary of Structuralist Literary Theory and Criticism is in many ways a summative moment in the Czech history of the 
discipline, bringing together several generations of scholars. It is also a nexus of several strands of effort and divergent initiatives, and this should also be celebrated. One could call this the paying off of an epistemic debt. First and foremost, the dictionary organically synthesises - without streamlining or epistemically reducing - the writings and scholarship engendered in the Czech lands in regimes of semiofficiality or illegality; parallel intellectual efforts abroad, both Structuralist in kind and derivative; and, the philosophical developments in related disciplines, such as cognitive linguistics and psychology, as well as narratology. It may seem that such a synthesis would be automatically expected of any such dictionary. (Still, I would also wish for the gap to be bridged with the recent followers of Russian theorists in countries of the former Eastern Bloc.)

However, there is an important qualification to consider: This book is published in Czech and it brings together not only foreign literature but also many of the seminal works of twentieth-century theory that have been published in Czech only recently, often after a gap of several decades. It is this epistemic debt within the Czech culture that this dictionary helps to pay off. In this important effort, there are three special mentions to be made: first, the Czech Academy of Sciences and the Grant Agency who have been supporting the efforts; next, the new generation of scholars, illustriously led here by the editor Ondřej Sládek. And, finally and most importantly, the publishing house Host, who has taken the lion's share in the effort to pay off this cultural debt over the last three decades. Host's dedication to criticism and theoretical literature - both Czech and international - is exemplary. As readers and scholars, we have much to be grateful for to all three of these corporate benefactors. 